\title{
企业成本会计发展趋势分析及对策浅析
}

\author{
陈明 \\ 铜陵有色金属集团股份有限公司金威铜业分公司 \\ DOI:10.12238/ej.v3i4.500
}

\begin{abstract}
[摘 要] 企业发展的核心是经济效益最大化, 在当前经济发展进程中, 成本会计所发挥的重要性逐渐受 到重视。在成本会计的管理范畴中, 对资源、管理和制造环境等均造成冲击。随着经济全球化竞争的逐 渐激烈, 企业成本会计的发展也在面临新的挑战和机遇。传统成本会计已经不再满足当前的经济发展需 要, 信息失真、延后等影响企业管理者的决策, 不利于企业的发展。由此可见, 企业会计成本需要不断的 发展和创新。本文对企业成本会计的影响因素、发展趋势和应对策略进行研究, 企业需要重视成本法和 成本会计发挥的理论和技术平台支持, 改进培训方式, 适应经济发展。
\end{abstract}

[关键词] 企业会计成本; 发展趋势; 对策; 分析

中图分类号: E232. 5 文献标识码: A

随着当前社会经济的快速发展, 企 业在经济核算体系中愈发重视成本会计 的作用, 逐渐完善企业的经营和发展。成 本会计所发挥的作用逐渐扩大, 但同时 也受到市场经济的制约 ${ }^{[1]}$ 。企业成本会 计需要遵循市场发展方向和规律, 提升 企业成本会计的重要地位, 促进其良性 发展。

\section{1 企业成本会计的影响因素}

1. 1成本会计界定内容

成本的本质是衡量价值范畴, 成本 会计工作的核心是核算企业在经营状态 下发生各种成本的费用, 通常默认为是 制造和生产成本。随着现代社会经济的 快速发展, 经济模式不断变化, 成本会计 概念也在不断升级。在国际经济发展中, 成本的含义在于目的性支付或应支付对 应货币中的价值牺牲, 从定义上看, 国际 成本会计的核算内容不仅在于产品的制 造成本, 如资金、开发和质量成本等。成 本会计在管理时需要深度考虑成本内涵, 并与管理者所需要的信息进行对接, 如 机会成本、目标成本和变动成本等。

在当前经济发展中, 成本会计的内 容需要考虑决策、计划、核算、控制、 预测、考核和分析等。当前成本会计在 管理过程中, 主要存在以下几点问题: 其 一, 重视产品、制造成本核算, 忽视对研
发、供应和销售等环节的成本核算。其 二, 成本会计的核心是核算, 为企业的经 济发展提供准确的成本信息, 为管理者 提供准确的成本管理信息, 但部分成本 核算存在管理混乱, 多种成本核算在一 起, 项目整理简单, 缺少成本控制的针对 性和专业性 ${ }^{[2]}$ 。当成本会计核算的信息 失真时, 会影响管理效果。企业管理层无 法明确各个部门存在的职责问题, 发生 事故时互相推诿。其三, 成本会计与财务 会计的关系, 针对成本核算的会计管理 存在多种学科的穿插, 管理会计的内容 包含成本控制, 成本决策和成本预测等。 成本会计也涉及财务管理的相关内容, 如成本计划、成本考核和分析等。在企 业成本会计的管理中, 管理力度还需要 加强, 未能深入发展的盲区, 影响成本会 计在企业中的发展。

\section{2成本会计受知识经济的冲击 \\ 在经济发展进程中, 经济的类型从} 物质经济逐渐转向信息、知识类经济。 企业在经营的过程中增加知识化、智能 化和数字化, 知识类资源对成本的消耗 也在不断增加。随着新型经济类型的发 展, 劳动力和资本在生产中消耗的比重 不断下降。传统的成本会计核算方式不 再满足当前新型管理的需求。由此可见, 成本会计在未来发展中, 需要对知识资
源消耗进行补偿。

企业在发展时要不断适应激烈的竞 争, 积极运用信息化技术来实现生产智 能自动化。例如金属企业在产品生产时, 借助计算机软件 (CAD系统) 进行设计, 在 工艺设计中, 借助辅助制造系统进行设 计, 加工产品时使用数控机床和弹性制 造系统进行加工。应用智能化地加工处 理, 企业生产产品质量在不断提升, 生产 领域对信息技术的广泛应用, 把控质量 与生产力, 降低企业劳动力成本, 提高生 产效率。企业管理者需要重视新型管理 理念的应用, 使企业的成本会计发生实 质性变化 ${ }^{[3]}$ 。传统的成本会计会增加企 业制造成本的复杂程度, 提高核算费用。 传统核算方式处理方式过于简单, 影响 企业的业务发展, 降低企业的竞争力。

\section{2 成本会计的未来发展趋势}

2. 1成本会计的形式改变

在当前信息技术的快速发展中, 会 计电算化已经取代传统的手工记账方式, 单位内部的信息系统可以确定出系统、 规范、及时的财务分析报告单。大型金 属企业对成本会计核算的要求增加, 需 要统一、综合和规范的进行尚品采购、 生产和出售等, 加强成本管控, 减少产品 生产、流通等各个环节所造成的不必要 浪费, 降低生产成本。企业内部各个部门 
需要进行辅助核算, 完善采购成本、生产 成本和销售成本, 实现强化企业内部管 理的目标。

2. 2 拓宽成本会计的使用空间

传统的企业会计成本重视生产和制 造, 但在当前的经济发展体系中, 服务型 领域、金融单位和事业单位等同样要重 视成本管理。为了更好适应新型制造发 展环境, 企业可借鉴国外作业成本管理 方式进行成本管理, 将质量检验、产品维 护和用户体验等费用均分摊在尚品的生 产费用中借助作业管理信息成本管理方 式, 提升产品质量和经济效益 ${ }^{[4]}$ 。

2. 3成本会计市场贴近全球化环境

成本会计的管理理念和方式源于制 造工艺和环境的发展和创新, 导致变化 的根本原因在于市场环境的变化。因此 企业在成本会计管理时要重视行业市场 的环境变化。在我国当前经济一体化的 发展背景下, 国内成本会计核算的要求 更加严格。多数生产制造的企业已经结 合先进的生产经营理念和方式进行成本 管理。加强成本控制, 提升管理水平, 有 助于企业与全球化经济环境的融合, 适 应先进的管理模式。

\section{3 加强成本会计管理的对策}

3. 1 深入研究成本管理理论

企业在发展过程中需要研究适合本 单位发展的成本会计管理理念, 体现我 国经济特色。成本会计的管理需要摒弃 传统会计管理的弊端, 创新开发新的研 究领域。在管理过程中需要以严谨作风、 务实态度和创新精神等为管理原则, 深 入研究企业经济发展与会计成本, 提升
成本会计管理对企业发展的助益, 发现 问题时及时处理。

3. 2 转变成本会计工作者的工作理念

在当前的经济发展中, 大部分企业 在进行经济效益核量时, 所参考的标准 就是成本。但从成本会计的核心管理理 念上看, 成本只是对某一段时间内发生 的消耗进行表现, 在实际耗费效益的分 析时, 仅从产品的成本指标无法评估实 际的成本。因此企业在进行成本绩效考 核时, 需要综合分析投入与产出之间的 关系 ${ }^{[5]}$ 。首先, 产品在产出时, 投入成本 越少越好, 其二, 在投入生产时, 产出越 多越好; 其三, 产出的增长多于投入越多 越好; 其四, 产出下降慢于投入越少越 好; 其五, 产出呈不断上升趋势, 投入呈 下降趋势越好。在实际成产中, 若单一降 低生产成本, 会降低增效支出, 影响生产 积极性。企业管理者需要转变成本会计 的管理理念, 稳定增效, 树立正确的成本 增效思想, 帮助企业制定增加科学的发 展对策 ${ }^{[6]}$ 。

3. 3推动成本会计电算化发展

在当前的成本会计管理中, 积极运 用计算机技术, 实现信息管理手段, 促进 未来发展。电子计算机技术的使用提升 了信息反馈的速度, 极大增强企业业务 的处理能力, 在成本预算、控制和决策等 方面更加准确和及时, 有效实施成本控 制策略, 分析成本。从发展上看, 企业成 本会计电算化的应用至关重要, 但当前 在实际应用中存在一些问题。首先是应 用形式, 虽然部分企业引入电算化, 但仅 仅是一种形式上的模仿, 取代手工核算,
虽然能提升信息处理和反馈效果, 但无 法在预测和决策上应用。其二是各个内 部系统的分离, 企业信息管理包含人事 系统、采购系统等, 但各个系统均是独立 存在的, 未能形成密切的联系。其三是会 计信息系统反馈的信息缺少全面性, 仅 反馈财务会计信息内容, 缺少对成本、管 理方面的汇报。为了推动会计电算化, 需要加快管理型的改变, 将会计信息与 企业管理系统更好的贴合。

3. 4 完善成本会计算法

我国企业在发展过程中不断对成本 会计进行总结和分析, 在成本会计的核 算方法上获得成效, 如项目测算法和作 业成本法等。算法执行的原则需要以人 为本, 积极进行职工管理和成本控制, 促 进现代成本会计的发展。作业成本法有 助于管理者对成本进行重新设计核算, 发挥更大价值。

\section{[参考文献]}

[1]齐梅.成本会计方法体系问 题 与对策创新研究 [J]. 商业时 代,2013,(14):70-71.

[2]梁金金, 张晓东,胡云峰. 企业成本 会计的发展存在问题与对策研究 [J]. 企 业导报.2016,(09):120-121。

[3]王宇晴.企业存货管理问题探讨 [J]. 黑龙江科学,2014,5(10):114-115.

[4]满国杰. 成本会计存在的问题及改 进措施[J]. 当代经济,2013,(22):136-137.

[5]周春芳.现代成本会计发展趋势及 对策研究[J].现代商业,2012,(12):271-272.

[6]李春宏,赵兵兵.成本会计的发展 趋势及对策[J].统计与咨询,2018,(04):36. 